\title{
Udział medycznych terminów zapożyczonych w XIX-wiecznych synonimach głównych (na materiale nazw chorób ze Stownika terminologii lekarskiej polskiej)
}

Słow a klucze: terminologia; polska terminologia medyczna XIX w.; synonimia; zapożyczenia

Key w ord s: terminology; Polish medical terminology of the $19^{\text {th }}$ century; synonymy; borrowings

Badania polskiego słownictwa medycznego różnych epok nie potwierdzają potocznego przekonania o jego znacznym nasyceniu zapożyczeniami. Dowodzą natomiast rodzimości polskiej terminologii lekarskiej, np. w XVI czy XVII wieku (Jankowiak 2005; 2009). Potwierdza ją również analiza materiału z XIX stulecia ${ }^{1}$. Rezultatem porządkowania polskiej terminologii lekarskiej w tym okresie przez polskich lekarzy było wydanie Stownika ter-

1 Niniejszy artykuł powstał na marginesie prac nad książką pt. Synonimia $w$ polskiej terminologii medycznej drugiej połowy XIX wieku (na podstawie Słownika terminologii lekarskiej polskiej z 1881 roku) [w druku]. 
minologii lekarskiej polskiej (Kraków 1881)². Było to pierwsze całościowe (czyli uwzględniające wszystkie działy szeroko pojętej ówczesnej medycyny) ujęcie ściśle naukowej warstwy terminologii medycznej. Stownik terminologii lekarskiej polskiej należy do słowników przekładowych. Składa się z dwóch części o różnej objętości. Pierwsza - ma około 20 tysięcy haseł obcojęzycznych (łacińskich, niemieckich, francuskich i rzadziej - angielskich) ułożonych alfabetycznie (w jedną listę). Do nich dopisano polskie odpowiedniki: czasem jeden termin, czasem - szereg synonimiczny polskich nazw. Część druga słownika obejmuje około 9 tysięcy (ułożonych alfabetycznie) nazw polskich, czyli tylko fragment leksyki obecnej w części pierwszej słownika. Do polskich terminów dołączono tylko niektóre obce hasła (głównie niemieckie i łacińskie) $)^{3}$.

Chociaż Słownik terminologii lekarskiej polskiej powstał w Krakowie, to - pomimo zaborów - uwzględnia też opinie innych środowisk lekarskich, głównie Warszawy, w mniejszym zaś stopniu - Poznania i Lwowa. Biorąc pod uwagę skomplikowane losy polskiego słownictwa lekarskiego w XIX wieku, należy uznać powstanie tego Stownika za ogromny sukces.

Jego koncepcja jest pomocna przy odtwarzaniu XIX-wiecznej teorii terminu, a dokładniej przy odpowiedzi na pytanie, jaki powinien być termin (np. jego budowa czy pochodzenie). Autorzy Stownika zastosowali bowiem w części pierwszej przy prezentacji polskich terminów (jako odpowiedników haseł obcojęzycznych) zasadę, że na pierwszym miejscu w takim szeregu synonimicznym polskich nazw (polskich synonimów) znajduje się termin najbardziej przez nich polecany. Nazywam go tu synonimem głównym.

Takie przedstawienie polskiego materiału w słowniku daje możliwość ustalenia m.in. tego, na ile często takim najlepszym terminem jest nazwa pochodzenia obcego. Celem niniejszego artykułu jest właśnie omówienie tego zagadnienia na przykładzie szeregów synonimicznych odnoszących się do nazw chorób 4 .

2 O budowie, koncepcji słownika oraz jego znaczeniu dla dziejów polskiej terminologii medycznej szerzej we wspomnianej książce. Por. też Jankowiak 2011.

3 Stąd jakakolwiek analiza materiału polskiego wymaga ekscerpcji materiału z części pierwszej Słownika. O problemach z ekscerpcją zob. w wyżej wymienionej (przygotowanej do druku) książce.

${ }^{4}$ Od razu trzeba zaznaczyć, że za zapożyczenia uznaję tu terminy przejęte z języka obcego (a więc także zapożyczenia właściwe, kalki strukturalne i kalki semantyczne) w okresie istnienia polszczyzny i w różnym stopniu polszczyźnie przyswojone. Podzie- 
Ze Stownika terminologii lekarskiej polskiej wyekscerpowałam 940 takich ciągów synonimicznych (składających się z 2 do nawet 12 terminów), gromadzących łącznie 2469 terminów (o zróżnicowanej budowie, tj. od jednoelementowych do ośmioelementowych). W 940 szeregach synonimicznych pojawiło się w sumie 57 zapożyczeń. Z tego zaledwie 15 (26,3\%) znajduje się na pierwszym miejscu w ciągu synonimicznym, czyli tylko 15 pożyczek jest synonimami głównymi.

Na wspomniane 15 zapożyczeń składają się greko-latynizmy ${ }^{5}$ (6: agrafija, cholera azjatycka, kamien' ${ }^{6}$, letarg, polip, wole), galicyzmy (6: artrytyzm, dyfteryja, epilepsyja, epilepsyja histeryczna, hipokondryja, histeryja), germanizmy (2: brak 1, brak 2) oraz jeden ukrainizm (czyrak) - zob. Tabela 1. Warto zwrócić uwagę, że zapożyczenia francuskie i ukraińskie ulokowały się tu w połowie swego zasobu. Z kolei $80 \%$ synonimów głównych ma korzenie łacińsko-romańskie.

Tabela 1. Geneza zapożyczeń

\begin{tabular}{|c|c|c|c|c|c|c|c|c|c|}
\hline $\begin{array}{c}\text { rodzaj } \\
\text { zapożyczenia }\end{array}$ & n.. & gr-lac. & fr. & nm. & ukr. & ang. & czes. & wl. & razem \\
\hline $\begin{array}{l}\text { liczba } \\
\text { synonimów } \\
\text { głównych }\end{array}$ & - & 6 & 6 & 2 & 1 & - & - & - & 15 \\
\hline $\begin{array}{l}\text { łączna liczba } \\
\text { zapożyczeń } \\
\text { w } 940 \text { szere- } \\
\text { gach }\end{array}$ & 5 & 27 & 12 & 8 & 2 & 1 & 1 & 1 & 57 \\
\hline
\end{tabular}

* O nieustalonej etymologii w literaturze przedmiotu.

Źródło: opracowanie własne

lam stanowisko leksykalistyczne, czyli przyjmuję, że nazwa pochodzi z języka, z którego wprost przedostała się do polszczyzny, a więc nie interesuje mnie, w jaki sposób dostała się do naszego języka. Z kolei derywaty od zapożyczeń włączam do leksyki rodzimej jako twory powstałe już na gruncie języka polskiego, np.: Skorupska-Raczyńska 1999: 215; por. Walczak 1992: 229.

${ }^{5}$ Pełny wykaz prac, z których korzystałam przy ustalaniu etymologii, jak również komentarze wyjaśniające zaklasyfikowanie danego terminu do określonej grupy genetycznej, zob. Jankowiak [w druku].

${ }^{6}$ W tym znaczeniu kamień jest kalką. 
Synonimy główne pochodzenia obcego - tu podkreślone - są przede wszystkim jednowyrazowe (13, np.: dyfteryja, [blonica]; hipokondryja, śledziennica, śledziennictwo; polip, † ukleja). Tylko w 2 szeregach synonim główny jest dwuelementowy (cholera azjatycka, cholera indyjska, cholera epidemiczna; epilepsya histeryczna, padaczka macinnicza).

Patrząc na budowę sąsiadujących terminów rodzimych, trzeba stwierdzić, że w 13 przypadkach na 15 , budowa synonimu głównego jest identyczna z następującym (następującymi) po nim terminem (terminami) rodzimym (rodzimymi), np.: agrafija, *bezpiśmienność; cholera azjatycka, cholera indyjska, cholera epidemiczna; czyrak, wrzedzionka; epilepsya histeryczna, padaczka macinnicza. Tylko w 2 ciaggach rodzime terminy sąsiadujące z synonimem głównym są (część z nich) o różnej i jednocześnie (część z nich) o identycznej budowie: epilepsyja, choroba św. Walentego, wielka choroba, $\dagger$ padaczka; letarg, śpiaczka zamartwa, †zachwat, †'śik.

Jedynie przy 2 pożyczkach, będących na pierwszym miejscu w szere$\mathrm{gu}$, pojawił się kwalifikator, w dodatku specjalistyczny ${ }^{\top}$ (patol. artrytyzm, $\dagger d n a$; patol. wole, wól), z czego wynika, że żaden z zapożyczonych synonimów głównych nie ma nacechowanego pochodzenia ${ }^{8}$.

Ciągi, w których pożyczki są synonimami głównymi, są przede wszystkim dwuelementowe (11, np.: histeryja, macinnica; polip, $\dagger$ ukleja; brak 2, nieobecność), jedynie po 2 szeregi są trójelementowe (hipokondryja, śledziennica, śledziennictwo; cholera azjatycka, cholera indyjska, cholera epidemiczna) i czteroelementowe (epilepsyja, choroba św. Walentego, wielka choroba, $\uparrow$ padaczka; letarg, śpiqczka zamartwa, $\dagger$ zachwat, $\uparrow$ śpik).

7 W Stowniku terminologii lekarskiej polskiej autorzy zastosowali różne kwalifikatory: literowe (skrótowe i opisowe) oraz graficzne. Biorąc pod uwagę podział znaczeniowy kwalifikatorów można powiedzieć, że autorzy słownika zastosowali przy nazwach chorób: kwalifikatory specjalistyczne, czyli odwołujące się do działów medycyny, np. chir., uznaje je za neutralne; kwalifikatory geograficzne, np. warsz.; kwalifikatory chronologiczne: dawniej, † (oznacza wyraz przestarzały lub wyszły z użycia), * (wskazuje na nowe wyrazy); kwalifikatory frekwencyjno-normatywne, np. [], () wskazujące na wyrazy rzadziej używane lub mniej właściwe; kwalifikatory stylistyczne, np. posp.

8 Autorzy Słownika terminologii lekarskiej polskiej nie stosują zbyt często kwalifikatorów. Jednak są one zróżnicowane (por. przypis 7.). Część z nich (tzn. bez kwalifikatorów specjalistycznych) wskazuje, jaką pozycję w języku miał dany termin przed włączeniem go do terminologii ściśle naukowej, czyli zapisaniem w Słowniku. Nazwy te wchodząc do Słownika tracą swoje nacechowanie, podwyższają rangę, a kwalifikatory jedynie przypominają o takim nacechowanym pochodzeniu. 
Jak wspomniałam, zapożyczone synonimy główne są pozbawione kwalifikatorów wskazujących na ich nacechowane pochodzenie. Jednak niekoniecznie jest tak w przypadku synonimów rodzimych znajdujących się obok. Co prawda w 8 przypadkach wyrazy rodzime znajdujące się na kolejnej (kolejnych) pozycji (pozycjach) w szeregu synonimicznym pozbawione są kwalifikatorów: brak 1, niedostatek; brak 2, nieobecność; cholera azjatycka, cholera indyjska, cholera epidemiczna; czyrak, wrzedzionka; epilepsya histeryczna, padaczka macinnicza; hipokondryja, śledziennica, śledziennictwo; histeryja, macinnica; patol. wole, wól. Jednak w pozostałych 7 przykładach sąsiadujące (niekoniecznie bezpośrednio) z synonimem głównym terminy rodzime mają od 1 (6, np.: patol. artrytyzm, $\dagger$ dna; epilepsyja, choroba św. Walentego, wielka choroba, † padaczka; polip, † ukleja) do 2 (1: letarg, śpiaczka zamartwa, † zachwat, † śpik) kwalifikatorów. Są to przede wszystkim kwalifikatory chronologiczne, wskazujące na dawność wyrazu (5, zob. ww. przykłady), lub - raz - na nowość terminu (agrafija, * bezpiśmienność). Pozostałe 2 ciągi zawierają termin rodzimy z kwalifikatorem frekwencyjno-normatywnym (dyfteryja, [błonica]) i geograficznym (kamień, warsz. kamiqczka). W szeregach tych logiczne wydaje się, że wygrał termin pierwotnie bez obciążeń poprawnościowych, czy o mniejszym zasięgu geograficznym.

Synonimy główne pochodzenia obcego są wśród 6 grup tematycznych wyróżnionych przeze mnie (ogół pożyczek był w 10 grupach), zob. Tabela 2. Zwraca uwagę, że najliczniej reprezentowane są w nazwach chorób układu nerwowego i narządów zmysłów (6). Wyróżnia się także jedyny przykład szeregu synonimicznego w nazwach chorób gruczołów dokrewnych - ma synonim główny pochodzenia obcego.

Nazwy pochodzenia obcego nie zostały przez autorów Słownika terminologii lekarskiej polskiej uznane za najodpowiedniejsze w grupie nazw chorób układu: trawiennego, moczowo-płciowego, oddechowego i krążenia.

$*$

W tworzonej w XIX wieku świadomie polskiej terminologii medycznej (tzn. porządkowanej dotychczasowej i uzupełnianej o nową w związku z pojawianiem się nowych desygnatów) udział zapożyczeń w ogóle (57), jak 


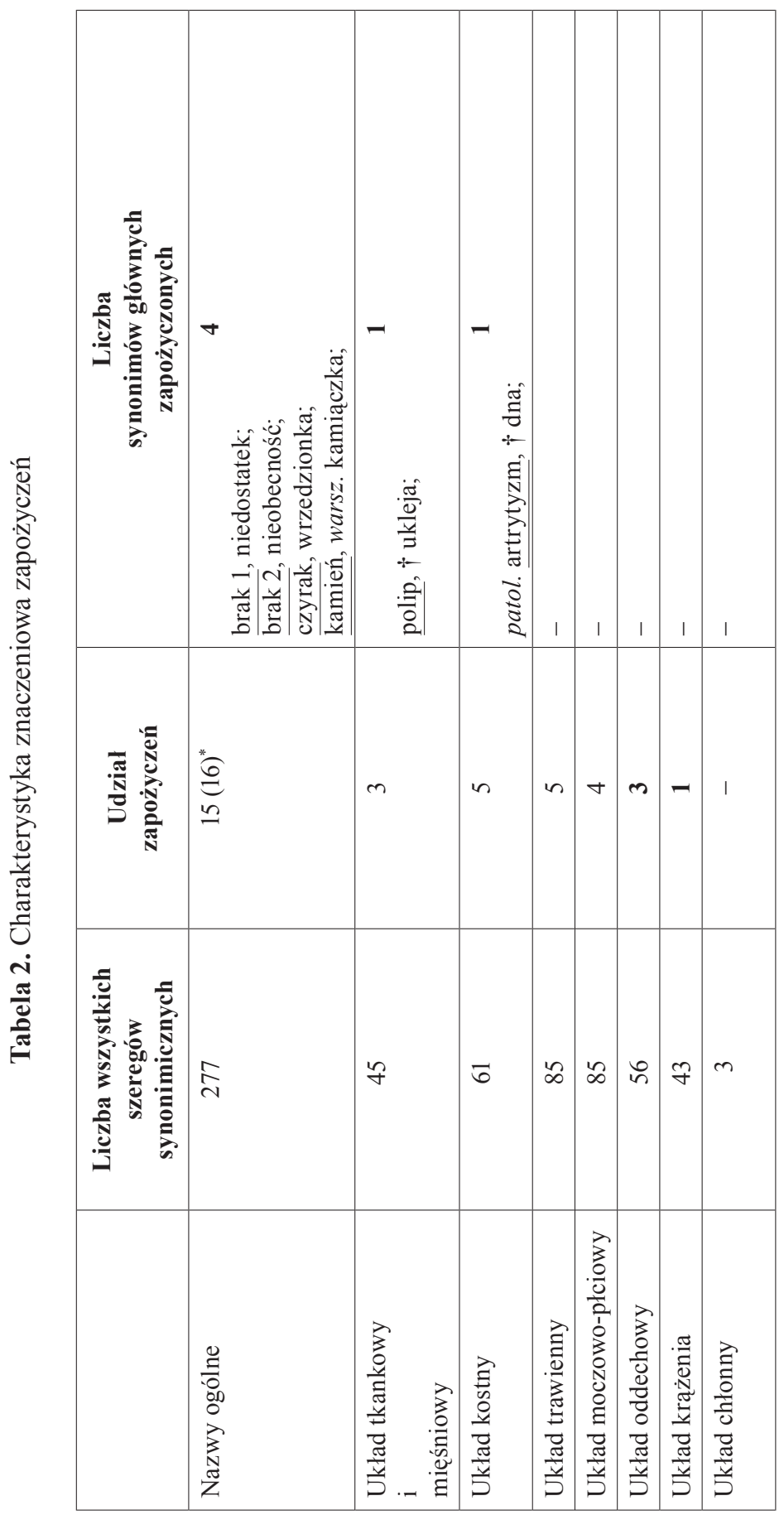




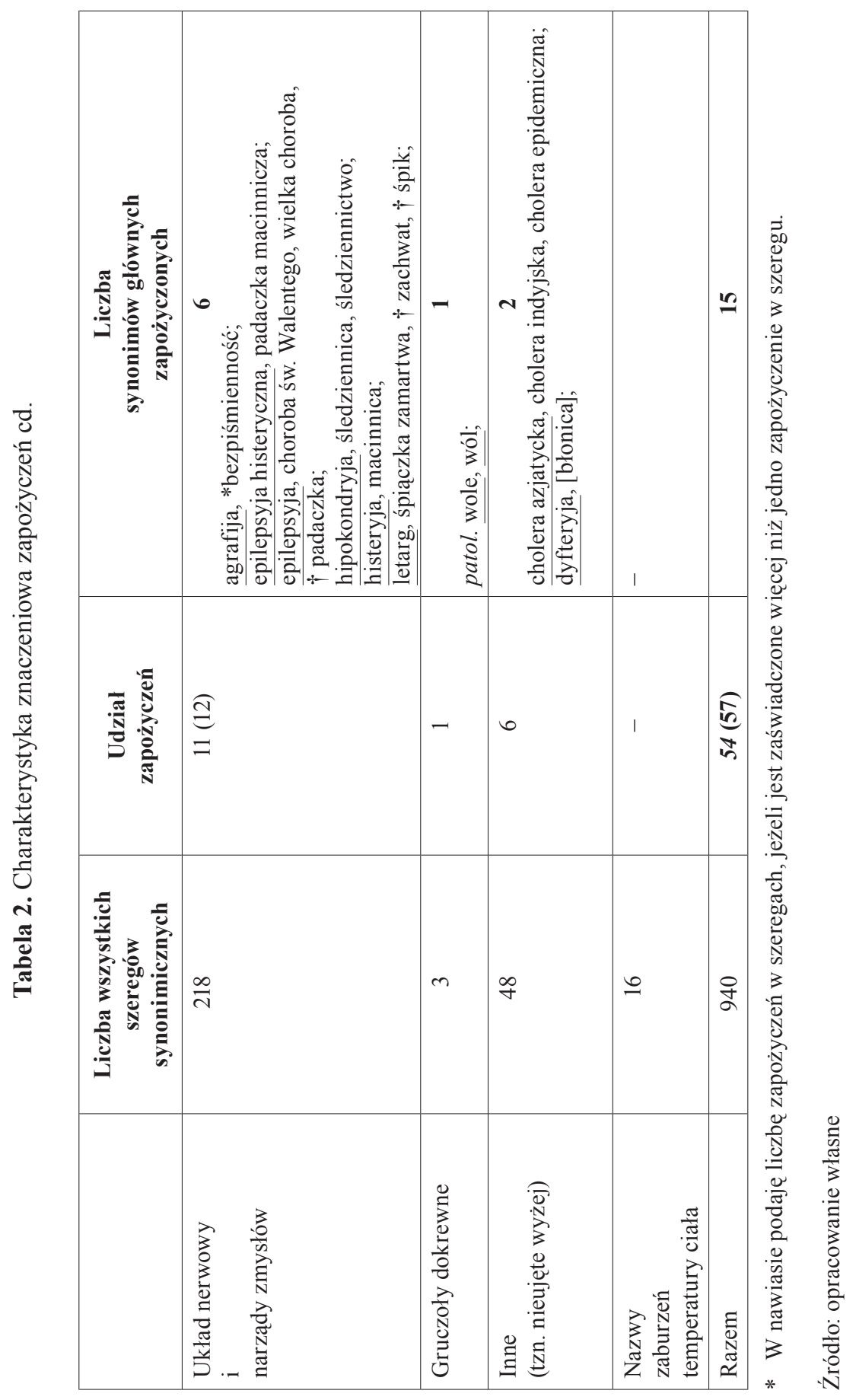


i zapożyczeń jako synonimów głównych nie jest znaczny (26,3\% z 57 zapożyczeń użytych w 940 szeregach synonimicznych). Dowodzi to zarówno zdecydowanej rodzimości polskiej terminologii medycznej, jak i oznacza, że (te nieliczne) terminy zapożyczone nie należą często nawet do nazw uznanych za najlepsze przez autorów Stownika terminologii lekarskiej polskiej. Twórcy słownika wyraźnie preferują terminy rodzime (925). Biorąc pod uwagę analizę wszystkich 57 zapożyczeń $^{9}$, trzeba dodać, że pożyczki w 940 szeregach synonimicznych usytuowały się głównie na ostatnim miejscu w tych szeregach (30 pożyczek). Oznacza to, że należą często, bo w ponad $50 \%$, do najrzadziej polecanych synonimów przez twórców XIX-wiecznej polskiej terminologii medycznej, mimo iż są to przecież w większości „ekonomiczne” (29) terminy jednowyrazowe.

Wśród zapożyczonych synonimów głównych przeważają latynizmy i galicyzmy (łącznie ponad 80\%). Pożyczki wygrały rywalizację o pierwsze miejsce w szeregach zwłaszcza wśród nazw chorób układu nerwowego i narządów zmysłów (z 12 terminów 6 jest pochodzenia obcego).

Jeśli na synonim główny (w przypadku nazw chorób) autorzy Stownika terminologii lekarskiej polskiej wybieraja już termin pochodzenia obcego, to o tym wyborze zdaje się decydować nienacechowane pochodzenie terminu oraz jego budowa, prostsza od budowy sąsiadujących z nim nazw rodzimych.

\section{Bibliografia}

JANIKOWSKI S., Oettinger J., Kremer A., 1881, Stownik terminologii lekarskiej polskiej, Kraków: Towarzystwo Lekarskie Krakowskie \{też: Śląska Biblioteka Cyfrowa\}.

Jankowiak L. A., 2005, Stownictwo medyczne Stefana Falimirza, t. 1: Poczatki polskiej renesansowej terminologii medycznej, Warszawa: Slawistyczny Ośrodek Wydawniczy.

Jankowiak L. A., 2006, Stownictwo medyczne Stefana Falimirza, t. 2: Stownik, Warszawa: Slawistyczny Ośrodek Wydawniczy.

JANKowiak L. A., 2009, Z dziejów terminologii medycznej. Słownictwo medyczne wieku XVI wobec XVII w. oraz pierwszej połowy XVIII w., Studia z Filologii Polskiej i Stowiańskiej 44, s. 61-83.

9 Zob. analiza w przygotowywanej przeze mnie książce. 
JANKOWIAK L. A., 2011, Polskie słownictwo medyczne w drugiej połowie XIX wieku oraz na przełomie XIX i XX wieku, Studia Jezzykoznawcze. Synchroniczne i diachroniczne aspekty badań polszczyzny 10, s. 97-109.

JANKowiak L. A., [w druku], Synonimia w polskiej terminologii medycznej drugiej połowy XIX wieku (na podstawie Słownika terminologii lekarskiej polskiej z 1881 roku).

Skorupska-Raczyńska E., 1999, Progresywne zapożyczenia pochodzenia łacińskiego w Dykcjonarzu Michała Amszejewicza, w: M. Białoskórska (red.), Synchroniczne i diachroniczne aspekty badań polszczyzny, t. 5: Materiały VII Kolokwium Językoznawczego Gorzów Wielkopolski, 16-18 czerwca 1997 r., Szczecin: Wydawnictwo Naukowe Uniwersytetu Szczecińskiego, s. 213-227.

WalCZAK B., 1992, Granica między jednostkami leksykalnymi rodzimymi i obcego pochodzenia, w: A. Markowski (red.), Opisać słowa. Materiaty ogólnopolskiej sesji naukowej w rocznice śmierci Profesor Danuty Buttler „,Teoretyczne i metodologiczne zagadnienia leksykologii”, Warszawa: „Elipsa”, s. 222-232.

WaLCZAK B., 1997, Słownictwo obcego pochodzenia na warsztacie badacza: problem granic (,głębokości”) opisu genetycznego, w: H. Popowska-Taborska (red.), Leksyka słowiańska na warsztacie językoznawcy, Warszawa: Slawistyczny Ośrodek Wydawniczy, s. 269-280.

WalczaK B., 1999, Zapożyczenia leksykalne: teoria i metodologia badań, w: B. Nowowiejski (red.), Polszczyzna pótnocno-wschodnia 2, Białystok: Wydawnictwo Uniwersytetu w Białymstoku, s. 69-107.

\section{Share of Borrowed Medical Terms in the $19^{\text {th }}$ Century Main Synonyms (on the base of the names of diseases from the Dictionary of Polish Medical Terminology)}

\section{( su m mary)}

The ordering of the Polish medical terminology in the $19^{\text {th }}$ century resulted in the release of the Dictionary of Polish Medical Terminology (Polish: Stownik terminologii lekarskiej polskiej) in 1881. The publication collected, among other things, synonymic series of Polish medical terms following the rule that the best term was listed as the first one, which in this paper, is referred to as the main synonym. The aim of the article is to present the frequency of instances when the main synonym is a borrowing. The analysis of 940 synonymic series concerning the names of diseases reveals that borrowings are rare in the analysed material (only 57 out of the 2,469 terms in the synonymic series). A borrowing (mainly from Greek and Latin) constitutes the main synonym only 15 times. The authors of the Dictionary preferred native terms despite the fact that foreign ones are usually more "economical" (e.g. with regard to their structure). 
